FIU Law Review

Fall 2015

Defending Israelis or Suppressing Palestinian Self-Determination? An Analysis of Operation Protective Edge Using the Two-Factor Test

Wajiha Rais

Florida International University College of Law

Follow this and additional works at: https://ecollections.law.fiu.edu/lawreview

Part of the Other Law Commons

Online ISSN: 2643-7759

Recommended Citation

Wajiha Rais, Defending Israelis or Suppressing Palestinian Self-Determination? An Analysis of Operation Protective Edge Using the Two-Factor Test, 11 FIU L. Rev. 255 (2015).

DOI: https://dx.doi.org/10.25148/lawrev.11.1.17

This Comment is brought to you for free and open access by eCollections. It has been accepted for inclusion in FIU Law Review by an authorized editor of eCollections. For more information, please contact lisdavis@fiu.edu. 


\title{
Defending Israelis or Suppressing Palestinian Self-Determination? An Analysis of Operation Protective Edge Using the Two-Factor Test
}

\author{
Wajiha Rais*
}

On July 7, 2014, Israel launched its third military offensive in Gaza in six years, dubbed Operation Protective Edge. ${ }^{1}$ The Operation lasted for fifty days before Israel and Hamas agreed to an Egyptian brokered cease-fire on August 26, 2014. ${ }^{2}$ According to the United Nations, 2,131 Palestinians were killed during the offensive, of whom 1,473 were civilians. ${ }^{3}$ On the Israeli side, seventy-one people died, of whom four were civilians. ${ }^{4}$

Israel justified the offensive as an act of self-defense against indiscriminate rocket attacks ${ }^{5}$ and the so-called "terror tunnels." The "terror tunnels" were a network of underground tunnels that went from Gaza to Israeli territory. ${ }^{7}$ In an interview with Fox News, Israeli Prime Minister, Benjamin Netanyahu, reiterated that "Israel... is defending its people as any country would under similar circumstances." 8 On its official blog, the Israel Defense Forces (IDF) stated that a goal of Operation Protective Edge is to "stop Hamas' incessant rocket attacks against Israel's

J.D. Candidate 2016, Florida International University College of Law. I would like to acknowledge Professors Noah Weisbord and Charles Jalloh for providing insight and advice that assisted my research and writing.

1 Rocket Attacks on Israel from Gaza, IDF BLOG, www.idfblog.com/facts-figures/rocket-attackstoward-israel (last visited Mar. 13, 2015) [hereinafter Rocket Attacks on Israel from Gaza].

2 William Booth \& Ruth Eglash, Israel, Hamas Reach Cease-Fire Deal Brokered by Egypt, WASH. Post (Aug. 26, 2014), www.washingtonpost.com/world/middle_east/israel-hamas-reach-ceasefire-deal-brokered-by-egypt/2014/08/26/cc834c02-2d49-11e4-bb9b-997ae96fad33_story.html.

3 Gaza Emergency Situation Report (as of 4 September 2014, 08:00 hrs), UNITED NATIONS OFFICE FOR THE COORDINATION OF HUMANITARIAN AFFAIRS, OCCUPIED PALESTINIAN TERRITORY 1 (Sept. 4, 2014), www.ochaopt.org/documents/ocha_opt_sitrep_04_09_2014.pdf.

$4 \quad$ Id. at 2.

5 Netanyahu: Some in West Say They Support Israel's Right to Defend Itself as Long as We "Don't Exercise That Right", CBS DC (July 22, 2014), washington.cbslocal.com/2014/07/22/ netanyahu-some-in-west-say-they-support-israels-right-to-defend-itself-as-long-as-we-dont-exercisethat-right [hereinafter $C B S D C]$.

6 The IDF's Mission in Gaza: Destroy Hamas Terror Tunnels, IDF BLOG (July 17, 2014), www.idfblog.com/blog/2014/07/17/idf-begins-ground-operation-gaza.

7 These tunnels, built by Hamas, reach up to thirty meters below the ground. In 2006, the tunnels were used to capture Israeli soldier, Gilad Shalit. Timeline 1,940 Days from Gilad Shalit's Abduction to His Release, HAARETZ (Oct. 11, 2011), www.haaretz.com/news/diplomacy-defense/timeline-1-940days-from-gilad-shalit-s-abduction-to-his-release-1.389452.

8 CBS DC, supra note 5. 
civilians" " while Netanyahu said that the Operation will continue until the tunnels are destroyed..$^{10}$ The message behind the statements is clear-Israel is defending itself against Palestinian rockets and tunnels. United States President, Barack Obama, echoed this message when throughout the Operation, he reaffirmed Israel's "right to defend itself." 11

Not everyone agrees with the characterization of Israel's actions as self-defense. During the Operation, John Dugard wrote an op-ed titled, "Debunking Israel's Self-Defense Argument," in which he argued that Israel's offensive "must [not] be seen as an act of self-defense by a state subjected to acts of aggression by a foreign state or non-state actor. Instead, it should be seen as the action of an occupying power aimed at maintaining its occupation." $12 \mathrm{He}$ reiterated this argument the following week in an interview with Amy Goodman on an episode of DEMOCRACY Now! ${ }^{13}$ The Russell Tribunal on Palestine ${ }^{14}$ similarly found that "people living under colonial rule or foreign occupation are entitled to resist occupation" and that "Israel's actions are those of an occupying power using force to maintain its occupation and to suppress resistance, rather than a state resorting to force in lawful self-defense." 15

How Israel's actions are characterized carries legal significance. The use of force in self-defense is an "inherent right" of States under Article 51

$9 \quad$ Rocket Attacks on Israel from Gaza, supra note 1.

10 Steve K. Walz, Netanyahu: Gaza Operation Will Continue Until Terror Tunnels Are Neutralized, JEwISH PRESS (July 30, 2014), www.jewishpress.com/special-features/israel-at-waroperation-protective-edge/netanyahu-gaza-operation-will-continue-until-terror-tunnels-are-neutralized/ 2014/07/30.

11 See Joseph Lederman, Obama: "Israel Has the Right to Defend Itself", HufFington POST (July $\quad 14, \quad 2014, \quad 8: 18 \quad$ PM), www.huffingtonpost.com/2014/07/15/obama-israel-ceasefire_n_ 5586229.html; Obama: Israel Has Right to Defend Itself, PRESS TV (July 27, 2014, 10:32 PM), www.presstv.com/detail/2014/07/27/373040/obama-israel-has-right-to-defend-itself.

12 John Dugard, Debunking Israel's Self-Defense Argument, AL JAZEERA AMERICA (July 31, 2014, 6:00 AM), http://america.aljazeera.com/opinions/2014/7/gaza-israel-internationalpoliticsunicc. html.

13 Can Israel Claim Self-Defense Against the Territory It Occupies? Int'l Jurist John Dugard Says No, DEMOCRACY NOw! (Aug. 6, 2014), www.democracynow.org/2014/8/6/can_israel_claim_self_ defense_against.

14 "The Russell Tribunal has no legal status but acts as a court of the people, a Tribunal of conscience, faced with injustices and violations of international law, that are not dealt with by existing international jurisdictions, or that are recognised but continue with complete impunity due to the lack of political will of the international community... [ [The Tribunal] is composed of eminent people from all states.... [Its legitimacy] does not come from a government or any political party but from the prestige, professional interests and commitment to fundamental rights of the Members that constitute [the] Tribunal." About, RUSSELl TRIBUnAL ON PALESTINE, www.russelltribunalonpalestine.com/en/ about-rtop (last visited Apr. 9, 2015).

15 Russell Tribunal on Palestine Emergency Session on Gaza 30, RUSSELl TRIBUNAL ON PALESTINE (Sept. 24, 2014), www.russelltribunalonpalestine.com/en/wp-content/uploads/2014/09/TRPConcl.-Gaza-EN.pdf. 
of the U.N. Charter and one of only two exceptions to the Charter's ban on the use of force under Article 2(4). ${ }^{16}$ Furthermore, the International Court of Justice (ICJ) confirmed that Israel has both the right and a duty to protect its inhabitants. ${ }^{17}$ The use of force for the purpose of suppressing a people's struggle for self-determination, on the other hand, is prohibited under international law. ${ }^{18}$ While the former purpose behind the use of force is legal, the latter is illegal. The question, which follows, is how does one determine whether force was employed for the legitimate purpose of protecting citizens or for the illegal purpose of suppressing a people's struggle for self-determination? Neither the State of Israel nor Dugard explain how they arrived at their respective characterizations of Operation Protective Edge. In fact, existing international law does not provide us with any test, guideline, or legal framework to make this difficult determination. The law, as it currently exists, is inapt at dealing with the interplay of force and self-determination as it takes place in the Israel-Palestine conflict. This Comment proposes a two-factor test to fill this gap in the law.

This Comment is divided into seven sections. The first provides a brief background of the law on self-determination, including the right to use force by national liberation movements and occupying powers. The following three sections demonstrate the inaptness of existing law, in the context of the Israel-Palestine conflict, to provide an answer to the question of when force by an occupying power is for the legitimate purpose of protecting its inhabitants and when it is for the illegitimate purpose of suppressing self-determination. The second section argues that jus in bello, or international humanitarian law (IHL), is unsuited to answer the question at issue because it only regulates how war is conducted and is unconcerned with the reasons for the use of force. This section further argues that occupation law, in general, is wholly unsuited to the Palestinian situation because it was created to regulate European occupations, which unlike Palestine did not involve liberation struggles. The third section explains that in light of the ICJ's Wall advisory opinion, the law of self-defense too is unsuited to the Israel-Palestine situation. The fourth section concludes that the doctrine of necessity, codified in the Articles on Responsibility of States for Internationally Wrongful Acts, ${ }^{19}$ does not help either since it presumes a

16 The other exception is the use of force by authorization of the U.N. Security Council under Chapter VII of the U.N. Charter.

17 Legal Consequences of the Construction of a Wall in the Occupied Palestinian Territory, Advisory Opinion, 2004 I.C.J. 136, 141 (July 9) [hereinafter Wall opinion].

18 HEATHER A. Wilson, InTERNATIONAL LAW AND THE USE OF ForCE By NATIONAL LIBERATION MOVEMENTS 135-36 (1988).

19 Draft Articles on Responsibility of States for Internationally Wrongful Acts, with Commentaries, [2001] Y.B. Int'l L. Comm'n 31, art. 25, U.N. Doc. A/56/10 [hereinafter Draft Articles on Responsibility of States]. 
wrongful act, which leads us back to the question of whether the use of force was in fact wrong (i.e., whether it was used to suppress selfdetermination). To answer the question at issue, the fifth section proposes the following two-factor test: (1) was force necessary to combat the threat to the occupier's inhabitants; and (2) did force go beyond that which was necessary to combat the threat? The sixth section applies this test to the threat of tunnels in Operation Protective Edge in order to determine whether Israel used force in pursuit of a legitimate security operation or if its aim was to suppress the Palestinians' struggle for self-determination. The seventh section concludes with a summary of the argument.

\section{SECTION I: SELF-DETERMINATION AND THE RIGHT TO USE FoRCE BY NATIONAL LIBERATION MOVEMENTS AND OCCUPYING POWERS}

\section{The Right to Self-Determination}

The concept of national self-determination has its historical roots in the concept of popular sovereignty proclaimed by the French Revolution. ${ }^{20}$ Self-determination, at the time of the French Revolution, meant selfgovernment; a government should reflect the will of the demos. Because self-determination posed a threat to the established order, for a long time it was considered a political issue and was not accorded a legal status. ${ }^{21}$ However, the concept made a popular return after the First World War. ${ }^{22}$ The pressures of decolonization accelerated the acceptance of selfdetermination as a legal right. ${ }^{23}$ Today, it is "difficult to deny the right of self-determination a true legal status." ${ }^{24}$ Although it had contentious beginnings, the principle of self-determination is now "firmly established in international law." 25 The ICJ, in its 2004 advisory opinion, reaffirmed the principle of self-determination and reiterated its status as a right erga omnes - meaning it is a concern of all States. ${ }^{26}$

Interestingly, no explicit mention of self-determination appears in the Covenant of the League of Nations. ${ }^{27}$ The concept was only "indirectly

20 A. Rigo Sureda, The Evolution of the Right of Self-Determination 17 (1973).

21 Id. at 25-6; JAMES CRAWFORD, THE CREATION OF STATES IN INTERNATIONAL LAW 108 (2d ed. 2006) ("Self-determination as a legal right or principle threatened to bring about significant changes in the political geography of the world, not limited to the dismemberment of Empires.... [I]t was potentially a most significant exception to the traditional view that the creation of States is a matter of fact and not of law.").

22 SUREDA, supra note 20, at 20.

23 Id. at 27.

24 Id.; CRAWFORD, supra note 21, at 122, 127.

25 CRAWFORD, supra note 21, at 122.

26 Wall opinion, supra note 17, 9 ฯ 88, 118.

27 League of Nations Covenant. 
recognized as applicable to the territories placed under mandate." 28 These were territories which, after the First World War, were no longer under the sovereignty of States that previously governed them and its people were not yet considered capable of self-government. ${ }^{29}$

The U.N. Charter, on the other hand, does include the word, "selfdetermination," in Article 1(2) and in the preamble of Article 55. ${ }^{30}$ The Charter states that the purpose of the United Nations (U.N.) is "[t]o develop friendly relations among nations based on respect for the principle of equal rights and self-determination of peoples, and to take other appropriate measures to strengthen universal peace." ${ }^{31}$ The International Covenant on Economic, Social, and Cultural Rights (ICESCR) and the International Covenant on Civil and Political Rights (ICCPR) also reaffirm the right of all peoples to self-determination. ${ }^{32}$

Despite the official recognition of the right to self-determination in the U.N. Charter, it was unclear for some time who the subjects of selfdetermination were. ${ }^{33}$ In other words, exactly who or which "peoples" had the right to self-determination? Sir Ivor Jennings eloquently stated the following:

Nearly forty years ago a Professor of Political Science who was also President of the United States, President Wilson, enunciated a doctrine which was ridiculous, but which was widely accepted as a sensible proposition, the doctrine of self-determination. On the surface it seemed reasonable: let the people decide. It was in fact ridiculous because the people cannot decide until somebody decides who the people are. ${ }^{34}$

Debates in the Coordination Committee during the drafting of the U.N. Charter reveal problems relating to the meaning of the word "peoples." 35 There were disagreements among States on the use of the word "peoples" and what this meant vis-à-vis the terms "nation" and "state." ${ }^{36}$ In response to the confusion, the Secretariat clarified in a memorandum that "peoples"

28 SuREDA, supra note 20, at 96 (quotations omitted); 2 DAVID HUNTER MiLlER, THE DRAFTing OF THE COVENANT 12-13 (1928).

29 League of Nations Covenant art. 22; SUREDA, supra note 20, at 97.

30 U.N. Charter art. 1, $\uparrow 2, \&$ art. 55.

31 U.N. Charter art. 1, ๆ 2.

32 International Covenant on Economic, Social and Cultural Rights, Dec. 16, 1966, S. Treaty Doc. No. 95-19, 6 I.L.M. 360, art. 1 (1967); International Covenant on Civil and Political Rights, Dec. 16, 1966, S. Treaty Doc. No. 95-20, 6 I.L.M. 368, art. 1 (1967).

33 SUREDA, supra note 20, at 28; see CRAWFORD, supra note 21, at 125.

34 Sir IVOR W. JENNINGS, THE APPROACH TO SELF-GOVERNMENT 55-56 (1956).

35 SUREDA, supra note 20, at 99.

36 Id. at $99-100$. 
refers to "group of human beings who may, or may not, comprise states or nations." ${ }^{37}$ Self-determination covers a group of peoples, nations, and States. ${ }^{38}$ Thus, the U.N. Charter not only recognized a peoples' right to selfdetermination, but it also gave the word "peoples" the broadest possible meaning. ${ }^{39}$

With regard to the Palestinians, specifically, the ICJ noted in its advisory opinion in 2004 that Palestinians are indeed "peoples" with a right to self-determination. ${ }^{40}$ In fact, it stated, "[T] he existence of a "Palestinian people' is no longer in issue." ${ }^{41}$ The Court elaborated that the existence of a Palestinian people has been recognized even by Israel, whether in the exchange of letters between Yasser Arafat ${ }^{42}$ and Yitzhak Rabin ${ }^{43}$ or in the Israeli-Palestinian Interim Agreement on the West Bank and the Gaza Strip. $^{44}$

\section{The Use of Force by National Liberation Movements}

Interestingly, however, while a people have a right to selfdetermination, it does not automatically follow that they may use force in pursuit thereof. ${ }^{45}$ Despite the universal recognition and acceptance of a peoples' right to self-determination, consensus is lacking on whether force can be used in pursuit of that right. ${ }^{46}$

Historically, the right to use force was not extended to national liberation movements. ${ }^{47}$ This is because, traditionally, the right was understood to belong only to States and not to "peoples." more and more colonies started to gain independence following the Second World War, the notion that national liberation movements have a right to use force in pursuit of self-determination began to gain support. ${ }^{49}$ The rationale behind the shift was that "[i]f the continuance of colonial domination is contrary to the right of self-determination ... then the use of force to secure that right should not be condemned." 50

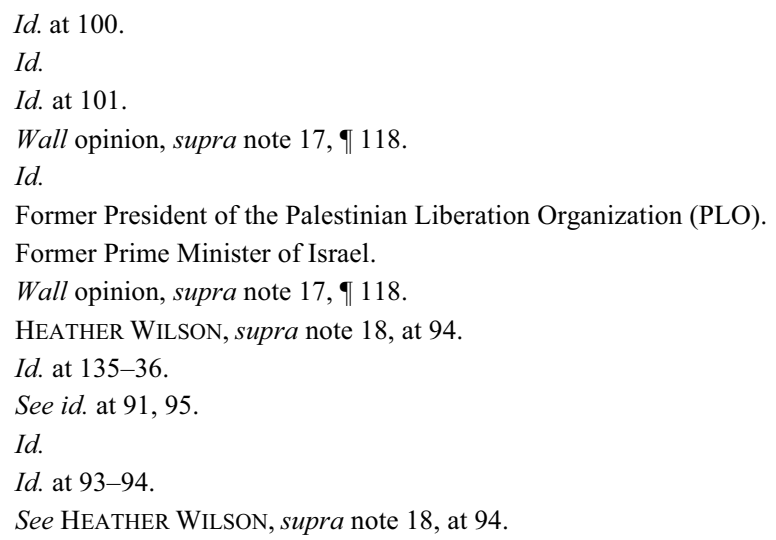


Support for the right of liberation movements to use force in pursuit of self-determination seems to be divided along political lines. ${ }^{51}$ The right "is actively supported by the newly independent States and the Eastern Bloc States, but has never been accepted by an established government confronting a liberation movement, or by the Western States." 52 The division and associated politics are pronounced in the several United Nations General Assembly (UNGA) resolutions passed on the subject. During the 1960s, an era of wide decolonization, the UNGA passed several resolutions recognizing the legitimacy of liberation movements' struggle to achieve self-determination. ${ }^{53}$ Due to disagreements between States, however, the resolutions avoided unequivocal language expressly condoning the right to use force as part of the struggle, so as to achieve a wide consensus among States. ${ }^{54}$

The Declaration on the Granting of Independence to Colonial Countries and Peoples, passed in 1960, was the first major resolution on decolonization. ${ }^{55}$ While it recognized the right of colonial people to struggle for independence, the resolution made no mention of an armed struggle. ${ }^{56}$ Then in 1965, the UNGA passed Resolution 2105 (XX) in response to Portuguese, South African and Rhodesian intransigence. ${ }^{57}$ The Resolution "recognize[d] the legitimacy of the struggle by the peoples under colonial rule to exercise their right to self-determination." ${ }^{58}$ While many States interpreted "struggle" to mean armed struggle, the colonial powers and the U.S. resisted this interpretation. ${ }^{59}$ This ambiguous word formed the standard language in subsequent resolutions on the subject throughout the 1960s. ${ }^{60}$

Some UNGA resolutions on Portuguese colonies and Namibia affirmed the legitimacy of the people to struggle for independence "by all means at their disposal." ${ }^{, 61}$ While a step forward, the resolutions once again fell short of unequivocally condoning the right to use force. The ambiguity

$51 \quad I d$. at 136.

$52 \quad I d$.

$53 \quad$ Id. at 96.

$54 \quad I d$.

55 G.A. Res. 1514 (XV), U.N. Doc. A/RES/1514 (Dec. 14, 1960); Christine Gray, INTERNATIONAL LAW AND THE USE OF FORCE 60 (3d ed. 2008).

56 GRAY, supra note 55; HEATHER WILSON, supra note 18, at 94.

57 G.A. Res. 2105 (XX), U.N. Doc. A/RES/2105 (Dec. 20, 1965); HEATHER WILSON, supra note 18 , at 95 .

58 G.A. Res. 2105 (XX), ๆ 10, U.N. Doc. A/RES/2105 (Dec. 20, 1965) (emphasis added).

59 HEATHER WILSON, supra note 18, at 94; see GRAY, supra note 55.

60 GRAY, supra note 55.

61 G.A. Res. 2708 (XXV), ๆ 5, U.N. Doc. A/RES/2708 (Dec. 14, 1970); G.A. Res. 2652, ๆ 1, U.N. Doc. A/RES/2652 (Dec. 3, 1970); G.A. Res. 3295 (XXIX), ๆ 3, U.N. Doc. A/RES/3295 (Dec. 13, 1974); GRAY, supra note 55, at 62. 
was deliberate so consensus among States could be achieved. ${ }^{62}$

In 1970, the UNGA passed by acclamation the Declaration on Principles of International Law, according to which,

every State has the duty to refrain from any forcible action which deprives peoples referred to above in the elaboration of the present principle of their right to self-determination.... In their actions against, and resistance to, such forcible action in pursuit of the exercise of their right to self-determination, such peoples are entitled to seek and to receive support in accordance with the purposes and principles of the Charter. ${ }^{63}$

Some took the above language, which was arguably stronger than that of previous UNGA resolutions, as confirmation of the right to use force by liberation movements. ${ }^{64}$ Others like Heather Wilson, however, argue that the language continues to be ambiguous and the resolution was passed unanimously precisely because "its more controversial provisions could be interpreted in a variety of ways." ${ }^{65}$ Despite the ambiguity, however, the debates on the resolutions reveal that most States understood the language to allow for armed struggle. ${ }^{66}$

The United Nations Security Council (UNSC) too passed several resolutions using the same ambiguous terms ${ }^{67}$ In 1966, for example, the UNSC passed a resolution recognizing the legitimacy of the "struggle" of the people of Southern Rhodesia. ${ }^{68}$ Just like the language in the UNGA resolutions, it was unclear whether "struggle" meant armed or simply peaceful struggle.

Conversely, resolutions that expressly recognized the right to use force were met with resistance from colonial powers and other Western States. ${ }^{69}$ Meanwhile, developing countries were adopting resolutions in international conferences explicitly recognizing the legitimacy of the right to use force in pursuit of self-determination. ${ }^{70}$ The ambiguous language of UNGA and UNSC resolutions, combined with significant support from Afro-Asian countries, but a lack of support from colonial and Western powers for

62 GRAY, supra note 55, at 62.

63 G.A. Res. 2625 (XXV), U.N. Doc. A/RES/2625 (Oct. 24, 1970); HEATHER WiLsON, supra note 18 , at 98 .

64 HEATHER WILSON, supra note 18 , at 99.

$65 I d$.

66 Id.

67 GRAY, supra note 55, at 62.

68 HEATHER WILSON, supra note 18, at 96; S.C. Res. 232, ๆ 4 (Dec. 16, 1966).

69 HeAther Wilson, supra note 18, at 96; see, e.g., G.A. Res. 3070 (XXVIII), at 78 (Nov. 30, 1973); G.A. Res. 39/72 (Dec. 13, 1984).

70 HEATHER WILSON, supra note 18, at 94-95. 
stronger language, reveals an obvious divide based on political and power interests.

Even if some States did not explicitly accept the authority of liberation movements to use force as a matter of law, their actions indicated acquiescence in some circumstances. ${ }^{71}$ Although some States did not openly condone the use of force by liberation movements, "they had at least begun to condemn the use of force by the colonial power, but not the liberation movement." ${ }^{72}$ For example, since the 1967 war in which Israel occupied territories belonging to its neighbors (and at least until 1973), there was a trend in UNSC resolutions to condemn Israeli use of force against "terrorist activities" coming from Jordan and Lebanon but to not similarly condemn Arab guerilla activity as illegal. ${ }^{73}$

The fact that the Security Council has never expressly condemned the guerilla activities of the Palestinians [emanating from Jordan and Lebanon] can be interpreted as an implied recognition of their right to recover at least the territories from which they were displaced in the June 1967 hostilities, and to do so by the use of force. ${ }^{74}$

In summary, a consensus is lacking on the right of liberation movements to use force for self-determination with colonial powers and other Western States generally opposing such a right while the developing world supporting it. Nevertheless, "the trend ... since 1960 in particular has been toward the extension of the authority to use force to national liberation movements." ${ }^{, 75}$ Meanwhile, according to James Crawford-judge at the ICJ-a non-State entity's right to use force for self-determination is "legally neutral" in the sense that it is "not regulated by international law at all." "76 Therefore, while it cannot unequivocally be said that Palestinians have the right to use force against Israel in their struggle for selfdetermination, nor can it unequivocally be said that they do not have such a right. While the law lacks a clear allowance for the use force by Palestinians, it also lacks a clear prohibition against their use of force.

\section{The Use of Force by an Occupying Power}

While the law is unclear on whether national liberation movements may use force in pursuit of their right to self-determination, it is very clear in prohibiting an occupying power from using force to suppress the

\footnotetext{
71 Id. at 103.

72 Id. at 111

73 SUREDA, supra note 20, at 343.

74 Id. at 343-44.

75 HEATHER WILSON, supra note 18, at 136.

76 CRAWFORD, supra note 21, at 135-36.
} 
people's struggle for self-determination. ${ }^{77}$ "[T] $[$ he use of force to deny the free exercise of a people's right to self-determination is contrary to the principles of international law." ${ }^{, 78}$ All occupations or administrations of territory by foreign powers are supposed to be temporary. Even though international law recognizes the state of occupation, such a state has always been understood as a temporary condition. A belligerent occupier is obligated to withdraw from occupied territories upon the cessation of hostilities. ${ }^{79}$ Because belligerent occupation is a consequence of war, "it is not political in its effects." ${ }^{80}$ Therefore, sovereignty is not transferred to the occupying power. ${ }^{81}$ Prolonged belligerent occupations in effect become annexations, in violation of international law.

An occupying power is not prohibited from using force under all circumstances. Rather, because an occupying power has the obligation to ensure public order and safety, it may use police force to that end. ${ }^{82}$ An occupier also "has the right, and indeed the duty to respond, in order to protect the life of its citizens." 83 Therefore, an occupying power may use force for certain purposes, but must never use force to suppress a people's struggle for self-determination. In fact, because self-determination is a right erga omnes, ${ }^{84}$ and has the status of a pre-emptory norm, ${ }^{85}$ all States are prohibited from suppressing this right whether by forceful or non-forceful means.

In summary, unlike the ambiguous nature of the law on the right of national liberation movements to use force, the law very clearly prohibits an occupying power from employing force to suppress self-determination. Meanwhile, an occupying power can use force for certain other purposes including protecting its population from attacks. ${ }^{86}$ Hence, while Israel may use force to protect its civilians from Palestinian attacks, it cannot use force to suppress the Palestinians' struggle for self-determination. The question that follows is, how does one know whether Israel is using force to protect its civilians or to suppress Palestinian self-determination? The following

77 Id. at $135-37,147$.

78 HEATHER WiLSON, supra note 18, at 135.

79 Occupation and International Humanitarian Law: Questions and Answers, ICRC (Aug. 4, 2008), www.icrc.org/eng/resources/documents/misc/634kfc.htm.

80 GEORGE GRAFTON Wilson, HANDBOOK OF INTERNATIONAL LAW 38 (1st ed. 1910).

$81 \quad I d$.

82 Tristan Ferraro (ed.), Occupation and Other Forms of Administration of Foreign Territory, ICRC (Mar. 2012), www.icrc.org/eng/assets/files/publications/icrc-002-4094.pdf; Hague Regulations, art. 43.

83 Wall opinion, supra note 17, \ 141.

84 Id. ๆๆ $88,118$.

85 Draft Articles on Responsibility of States, supra note 19, at art. 26 comm. (5).

86 Wall opinion, supra note 17, ๆ 141. 
three sections explore existing bodies of law (i.e., jus in bello or occupation law, law of self-defense and the doctrine of necessity) in search of an answer to this question. Because existing law does not provide any relevant guidance, Section $\mathrm{V}$ of the Comment proposes some factors to help answer the question.

\section{SECTION II: JUS IN BELLO AND THE LAW OF OCCUPATION}

This section looks at the jus in bello legal regime and the law of occupation. It explores the two in search of guidance to help answer the question that is at issue in this Comment. This section finds that the jus in bello legal regime offers no relevant guidance since it only governs how force is used once an armed conflict begins, and is unconcerned with the motives behind the use of force. The central question of this Comment, however, is concerned with only the motives of the State of Israel behind its use of force, and whether those motives are the protection of its civilians or the suppression of Palestinian self-determination. This section also finds that the law of occupation, in general, is inapt at dealing with the question at hand because occupation law developed outside the context of colonial occupations. ${ }^{87}$ It was historically meant only to regulate European occupations, which were not colonial occupations, and, therefore, occupation law does not take into account issues of self-determination. ${ }^{88}$

\section{Jus in Bello}

Jus in bello is the legal regime which regulates the conduct of war. ${ }^{89} \mathrm{It}$ is also referred to as international humanitarian law (IHL), the bulk of which is codified in The Hague Regulations, the Fourth Geneva Convention, and Additional Protocols I and II. The treaties, which form the core of IHL, are considered customary international law. This means that the treaties are binding on States even if they are not a party to them. The jus in bello legal regime is triggered once an armed conflict begins. ${ }^{90}$ The ICJ confirmed in its 2004 advisory opinion that international humanitarian law is applicable to the Occupied Palestinian Territory. ${ }^{91}$

87 Yutaka Arai-Takahashi, Preoccupied with Occupation: Critical Examinations of the Historical Development of the Law of Occupation, 94 INT'L REV. OF THE RED CROSS 51, 72 (2012) [hereinafter Arai-Takahashi, Preoccupied with Occupation].

$88 I d$.

89 KeIICHIRO OKIMOTO, THE DISTINCTION AND RELATIONSHIP BETWEEN JUS AD BELLUM AND JUS IN BELLO 8 (2011).

90 Robert Kolb, Origin of the Twin Terms Jus ad Bellum/Jus in Bello, ICRC RESOURCE CTR., (Oct. 31, 1997), www.icrc.org/eng/resources/documents/article/other/57jnuu.htm.

91 Wall opinion, supra note 17, ๆ 101. 
While the jus in bello legal regime is applicable to the Occupied Palestinian Territory, ${ }^{92}$ it is irrelevant to the question at issue in this Comment because jus in bello is not a legal basis for the legitimate use of force. It merely regulates how war is waged and is unconcerned with the reasons for waging war, let alone whether those reasons are legitimate or illegitimate. Such concerns fall under the domain of jus ad bellum instead. In fact, jus in bello rules of warfare apply to all parties to the conflict regardless of the legitimacy of their use of force or their status as victim or aggressor. ${ }^{93}$ In other words, just because a State waged an illegal war against another State, this does not mean that the victim State is not bound by jus in bello in its use of force against the aggressor State. The underlying interest, which jus in bello seeks to safeguard, is the protection of civilians. ${ }^{94}$ The equal applicability of jus in bello to both victim and aggressor ensures that civilians of the aggressor State are protected just like civilians of the victim State. ${ }^{95}$

Additionally, all parties to an armed conflict are bound to respect jus in bello rules of war regardless of the legality of their initial resort to force. This helps ensure that the aggressor State cannot flout its jus in bello obligations just because its initial resort to force was unlawful. If all military actions of a State, who unlawfully resorted to force, were considered illegal by virtue of the illegality of its initial resort to force, then the aggressor State would lack any incentive to restrict its military conduct according to IHL.

It is impossible to demand that an adversary respect the laws and customs of war while at the same time declaring that every one of its acts will be treated as a war crime because of the mere fact that the act was carried out in the context of a war of aggression. ${ }^{96}$

The otherwise lawful method of warfare by an aggressor State does not become unlawful merely because it violated jus ad bellum. ${ }^{97}$

Jus in bello is unconcerned with the reasons for using force but only with regulating conduct of hostilities once an armed conflict has begun. It is, therefore, irrelevant to the question whether an occupying power used force to protect its civilians or to suppress self-determination. The occupying power can abide by IHL but still employ force for the illegitimate purpose of suppressing a people's struggle for self-

93 Окімото, supra note 89, at 14-24; Francois Bugnion, Just Wars, Wars of Aggression and International Humanitarian Law, 84 INT'L REV. OF THE RED CROSS 523, 533-36 (2002).

94 Окімото, supra note 89, at 11.

95 Id. at 15.

96 Bugnion, supra note 93 , at 541.

97 Окімото, supra note 89 , at 29. 
determination. Its compliance (or non-compliance) with IHL says nothing about its motives for resorting to force. At most, it may be argued that a gross violation of jus in bello principles of military necessity and proportionality may indicate a motive that is other than the protection of civilians. Generally, however, jus in bello is irrelevant for purposes of the question that this Comment poses.

\section{The Law of Occupation}

One would assume that the most obvious law to consult for limits on the use of force by an occupying power is the law of occupation. ${ }^{98}$ However, even the law of occupation, in general, is not applicable to the central question of this Comment as it relates to the Israel-Palestine conflict. This is because the Israel-Palestine conflict is a "situation ... in which belligerent occupation and wars of national liberation overlap." 99 The law of occupation, on the other hand, was created to regulate European occupations, which unlike the occupation of Palestine, did not involve liberation struggles. ${ }^{100}$ Because existing occupation law developed outside the context of colonial occupations involving liberation struggles, it does not take into account the right of self-determination. ${ }^{101}$ It is, therefore, inapt to deal with issues of force in the context of self-determination, which do exist in the Israel-Palestine conflict.

Ideas of liberalism and freedom from monarchical rule laid the foundation for the development of the law of occupation. ${ }^{102}$ Such ideas swept across Western Europe from the end of the eighteenth century to the middle of the nineteenth century, challenging the monarchical political order of the continent. ${ }^{103}$ Revolutionaries waged wars in other countries in order to oust the ruling monarchy and liberate the oppressed local

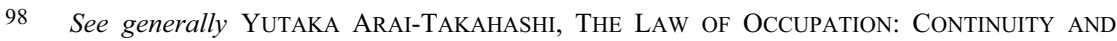
CHANGE OF INTERNATIONAL HUMANITARIAN LAW AND THE INTERACTION WITH INTERNATIONAL HuMAN RightS LAW (2009) [hereinafter ARAI-TAKASHI, THE LAW OF OCCUPATION].

99 HeATHER Wilson, supra note 18, at 20; see also Wall opinion, supra note 17, 9 ๆ 78, 118 (finding that Palestinian territory east of the Green line is occupied by Israel and that Palestinians are a "people" who have the right to self-determination).

100 Arai-Takahashi, Preoccupied with Occupation, supra note 87, at 72; Martti Koskenniemi, Occupied Zone_-"A Zone of Reasonableness"?, 41 ISR. L REV. 13, 30 (2008).

101 See Matthew Saul, Research Fellow at the Norwegian Centre for Human Rights and Lecturer at Durham University, U.K., Symposium on the Functional Approach to the Occupation of the Gaza Strip and the Right to Self-Determination (Apr. 25, 2012), http://opiniojuris.org/2012/04/25/the-func tional-approach-to-the-occupation-of-the-gaza-strip-and-the-right-to-self-determination (stating, "both Hague Law and Geneva Law were created before the emergence of the legal right to selfdetermination")

102 Arai-Takahashi, Preoccupied with Occupation, supra note 87, at 55.

$103 I d$. 
population. ${ }^{104}$ Since the revolutionaries waged war not to annex territory but to liberate the local population, the revolutionaries' interests were aligned with those of the locals. ${ }^{105}$ Thus, the occupying revolutionaries did not face resistance from the occupied population and there was no tension between the two. ${ }^{106}$ Occupation was meant to be temporary and, therefore, did not lead to liberation struggles. The law of occupation developed in this context as a way of managing the new European territorial order. ${ }^{107}$

After the French Revolution, occupation became distinct from conquest. ${ }^{108}$ In fact, the 1791 French Constitution stated, "[T] he French nation renounces the undertaking of any war with a view of making conquests, and it will never use its forces against the liberty of any people." ${ }^{109}$ Territory was no longer seen as belonging to the king, but rather as belonging to the people. ${ }^{110}$ Thus, ousting of the sovereign did not transfer sovereignty to the occupying power. ${ }^{111}$ This new conceptualization of sovereignty forms the basis of the "conservationist principle" 112 in the Fourth Geneva Convention whereby the occupying power is simply a custodian of the occupied territory who must preserve the status quo and does not have the sovereign authority to change existing laws. ${ }^{113}$ The occupying power merely fills a "temporary vacuum created by the ousting of the local government and maintain[s] its bases of power until the conditions for the latter's return are mutually agreed upon." 114 Thus, occupation law developed, as a theory distinct from conquest, to manage the newly emerging European political and territorial order.

It is not as if European powers at the time were not engaged in occupations for the purpose of annexing territory in which they faced resistance from liberation movements. In fact, the period of the collapse of the European monarchical political order was also the height of imperialism and colonialism. ${ }^{115}$ However, these "occupations [of non-European territories] that led to colonial control were placed outside the constraints of

\footnotetext{
$104 \quad I d$

105 Koskenniemi, supra note 100 , at 30.

$106 I d$

107 Arai-Takahashi, Preoccupied with Occupation, supra note 87; Koskenniemi, supra note 100.

108 Eyal BENVENisti, THE InTERNATIONAL LAW OF OCCUPATION 25 (2d ed. 2012).

109 French CONSTItUTION OF 1791; Arai-Takahashi, Preoccupied with Occupation, supra note

110 Arai-Takahashi, Preoccupied with Occupation, supra note 87, at 55.

111 Koskenniemi, supra note 100, at 26.

112 Gregory H. Fox, The Occupation of Iraq, 36 GEO. J. INT'L L. 195, 199 (2005).

113 Geneva Convention Relative to the Protection of Civilian Persons in Time of War art. 43, Aug. 12, 1949, 6 U.S.T. 3516, 75 U.N.T.S. 135 [hereinafter Fourth Geneva Convention].

114 BENVENISTI, supra note 108, at 69.

115 Arai-Takahashi, Preoccupied with Occupation, supra note 87, at 74.
} 87 , at 55 . 
the law of occupation." 116 Since sovereignty was a "gift of civilization," the law of occupation, which preserved the sovereignty of the occupied people, was applied only to "civilized" European nations and not to "uncivilized" non-European nations. ${ }^{117}$ Hence, the law of occupation was never developed to deal with colonial occupations involving liberation movements. In fact, the legal right of self-determination emerged after the creation of occupation law. ${ }^{118}$ In fact, until the period of decolonization in the mid-twentieth century, the law of occupation was considered a largely European project. ${ }^{119}$ It is, therefore, unsuited to the Israeli occupation of Palestinian Territory, which is both a belligerent occupation and a struggle for national liberation. ${ }^{120}$

The Law of Occupation, for example, permits the occupying power to require the occupied people to swear an oath of obedience (albeit not allegiance) whereby the occupied must behave in a peaceful manner, not take part in hostilities and obey the occupying power. ${ }^{121}$ Furthermore, occupied inhabitants who sabotage military institutions of the occupying power may be punished by death. ${ }^{122}$ The foundation of belligerent occupation, writes Yoram Dinstein, is the "power of the bayonet." ${ }^{23}$ This stands in stark contrast to the law of self-determination, which bans the use of force to suppress a people's struggle for self-determination. The contrast, which is due to the fact that the law of occupation developed separately from and before the legal right to self-determination ${ }^{124}$ shows that occupation law is ill-suited to colonial occupations involving national liberation struggles. ${ }^{125}$ Its rules on the use of force cannot be appropriately applied to the Israeli occupation of Palestine as they were never meant to regulate such an occupation. We, therefore, cannot look towards the law of occupation for an answer to the question, when use of force by an occupying power is for the illegitimate purpose of suppressing selfdetermination.

$116 \quad I d$. at 53.

117 Id. at 74.

118 Saul, supra note 101.

119 Arai-Takahashi, Preoccupied with Occupation, supra note 87, at 72.

120 See HEATHER WiLson, supra note 18, at 20.

121 ARAI-TAKASHI, THE LAW OF OCCUPATION, supra note 98, at 44; UNITED STATES DeP'T OF THE ARMY, THE LAW OF LAND WARFARE: FIELD MANUAL 27-10, 432 (1956).

122 Fourth Geneva Convention, supra note 113, art. 68.

123 YorAm DinStEIn, THE INTERNATIONAL LAW OF BELLIGERENT OCCUPATION 90 (2009).

124 Saul, supra note 101.

125 Arai-Takahashi, Preoccupied with Occupation, supra note 87. 


\section{SECTION III: THE LAW OF SELF-DEFENSE}

If not the law of occupation, perhaps the law of self-defense can help shed some light on the issue of when force used by an occupying power is legitimate and when it is for the illegitimate purpose of suppressing selfdetermination. The law of self-defense seems to be the obvious legal regime to consult given that self-defense is the justification that Israel presents for Operation Protective Edge - not surprisingly since other than U.N. Security Council authorization, it is the only legally valid reason for States to use force. This section finds, however, that the law of self-defense is inapplicable to the Israel-Palestine conflict because Article 51 traditionally does not encompass armed attacks by non-state actors, Security Council Resolutions 1368 and 1373 only refer to international terrorism, and the self-defense argument causes an impermissible confusion between the jus ad bellum and the jus in bello. It, therefore, cannot be relied upon to answer the question that is at issue in this comment.

The International Court of Justice's (ICJ) advisory opinion on the Legal Consequences of the Construction of a Wall in the Occupied Palestinian Territory provides valuable insight into the applicability (or lack thereof) of the law of self-defense to Israeli measures taken in response to terror attacks emanating from Palestinian territory. ${ }^{126}$ The Court addressed the following question in its opinion:

What are the legal consequences arising from the construction of the wall being built by Israel, the occupying Power, in the Occupied Palestinian Territory, including in and around East Jerusalem, as described in the report of the Secretary-General, considering the rules and principles of international law, including the Fourth Geneva Convention of 1949, and relevant Security Council and General Assembly resolutions? ${ }^{127}$

Even though the construction of the wall was a non-forceful measure as opposed to the forceful measures used in Gaza, the opinion is still relevant to Operation Protective Edge. If the law of self-defense is inapplicable to Israel's non-forceful responses to terror attacks, then it is certainly inapplicable to its forceful measures.

Israel justified its construction of the wall, which as planned incorporated about sixteen percent of the West Bank between the wall and the Green Line, ${ }^{128}$ as an act of self-defense against terror attacks emanating 
from the West Bank. ${ }^{129}$ It relied on Article 51 of the U.N. Charter, which affirms States' inherent right to defend themselves from armed attacks. ${ }^{130}$ The ICJ, however, found that Article 51 had "no relevance in this case" because the attacks are not "imputable to a foreign State," "131 suggesting that Article 51 self-defense can only be invoked against an attack by a State.

The Court has been criticized for failing to explain how it arrived at this conclusion given that the language of Article 51 itself has no requirements relating to the legal personality of the attacker. ${ }^{132}$ An explanation is unnecessary because the Court's interpretation of Article 51 is not novel but has been the generally accepted interpretation for over fifty years. ${ }^{133}$ Indeed, before the attacks on the World Trade Center, one would not have imagined that non-state actors could be capable of employing the kind of force that has traditionally only been within the purview of States.

However, global reality today is different and it is long recognized that "any interpretation of the U.N. Charter should allow for the evolution of the Organization [the U.N.] in accord with a changing global setting, especially in the area of international peace and security."134 Today's international community does not hesitate to acknowledge the right of States to defend themselves against armed attacks from non-state actors. The day after the terror attacks on the World Trade Center and the failed attack on the Pentagon, the U.N. Security Council unanimously passed Resolution 1368, which reaffirmed in the context of the attacks "the inherent right of individual and collective self-defense in accordance with the Charter." The same month, the Security Council unanimously passed Resolution 1373, which also reaffirmed the inherent right to self-defense in the context of acts of terrorism. ${ }^{136}$ This resolution was passed under Chapter VII of the U.N. Charter and is binding upon all U.N. member States. Therefore, at least since 2001, "state practice appears to support the permissibility of responding in self-defense to an attack by a non-state actor."137

129 Id. $\uparrow 116$.

$130 \quad$ Id. $\uparrow 138$.

131 Id. $₫ 139$.

132 Sean Murphy, Self-Defense and the Israeli Wall Advisory Opinion: An Ipse Dixit from the ICJ?, 99 AM. J. INT'L L. 62, 63 (2005).

133 Legal Consequences of the Construction of a Wall in the West Bank, Advisory Opinion, 2004 I.C.J. 136, 141 (July 9) (separate opinion of Judge Kooijmans) [hereinafter Wall separate opinion of Judge Kooijmans].

134 Richard Falk, Toward Authoritativeness: The ICJ Ruling on Israel's Security Wall, 99 AM. J. INT'L L. 42, 51 (2005).

135 S.C. Res. 1368, U.N. Doc. S/RES/1368 (Sept. 12, 2001) [hereinafter S.C. Resolution 1368].

136 S.C. Res. 1373, U.N. Doc. S/RES/1373 (Sept. 28, 2001) [hereinafter S.C. Resolution 1373].

137 Murphy, supra note 132, at 63. 
Contrary to several critics of the ICJ's Wall opinion, despite adopting a traditional interpretation of Article 51, the Court did not dismiss the right of a State to defend itself against armed attacks by non-state actors. ${ }^{138}$ In fact, the Court explicitly considered Israel's self-defense argument under U.N. Security Council Resolutions 1368 and $1373 .{ }^{139}$ However, it rejected this argument because the attacks at issue emanated from within, not outside, territory that Israel controls. ${ }^{140}$ Several critics are baffled by the Court's distinction, ${ }^{141}$ but a closer reading of the Court's opinion and Judge Kooijmans' separate opinion ${ }^{142}$ reveals that the distinction is well-founded. The language of Security Council Resolutions 1368 and 1373, on which Israel relied, refers to "international terrorism" which affects "international peace and security." "143 Insofar as terror attacks emanate from within territory occupied and controlled by Israel, "[t]he situation is ... different from that contemplated by Security Council resolutions." ${ }^{\text {"144 }}$ Consequently, the Court found that Israel could not invoke self-defense under these resolutions either.

There is yet another reason, not discussed by the Court in its opinion, for why Article 51 self-defense is inapplicable to Israel. In its oral statement to the ICJ, Palestine argued that invoking self-defense as justification for construction of the Wall causes "an impermissible confusion" between the jus in bello and the jus ad bellum, that "have to be kept radically apart."145 Palestine elaborated this point in its written statement:

The Fourth Geneva Convention permits forcible measures against civilian populations, subject to strict limits. That exhausts the legal rights of an Occupying Power. A State may not use all of its powers under the Fourth Geneva Convention and the Laws of War and then decide that those powers are inadequate and invoke the more general right of self-defense, which belongs to the jus ad bellum, in order to avoid the constraints of international humanitarian law. ${ }^{146}$

138 See, e.g., id.; Emanuel Gross, Combating Terrorism: Does Self-Defense Include the Security Barrier? The Answer Depends on Who You Ask, 38 CoRNELL INT'L L.J. 569 (2005); Ruth Wedgewood, The ICJ Advisory Opinion on the Israeli Security Fence and the Limits of Self-Defense, 99 AM. J. INT'L L. 52 (2005).

139 Wall opinion, supra note 17, 9 ฯ 138-39.

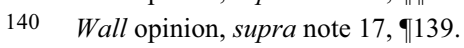

141 See, e.g., Wedgewood, supra note 138; Murphy, supra note 132.

142 Wall separate opinion of Judge Kooijmans, supra note 133, 936.

143 S.C. Resolution 1373, supra note 136.

144 Wall opinion, supra note 17, 9 139; Iain Scobbie, Words My Mother Never Taught Me "In Defense of the International Court”, 99 AM. J. INT'L L. 76, 82 (2005).

145 Legal Consequences of the Construction of a Wall in the Occupied Palestinian Territory, 2004 I.C.J. Pleadings 1, at 44-45 (Feb. 23, 2004).

146 Legal Consequences of the Construction of a Wall in the Occupied Palestinian Territory, 
Self-defense is a part of the jus ad bellum, which allows for wider scope of action than military necessity under jus in bello. ${ }^{147}$ By relying on jus ad bellum self-defense instead of military necessity in jus in bello, ${ }^{148}$ Israel is trying to "set aside IHL obligations" and "take a wider military action."149 Once an armed conflict has begun, the time to invoke self-defense has passed as the State has already resorted to force. ${ }^{150}$ Invoking self-defense as justification for Israeli measures against terror attacks is a misuse of the two abovementioned legal regimes.

The law of self-defense is inapplicable to the Israel-Palestine conflict because Article 51 traditionally does not encompass armed attacks by nonstate actors. Security Council Resolutions 1368 and 1373 only refer to international terrorism, and the self-defense argument causes an impermissible confusion between the jus ad bellum and the jus in bello. The law of self-defense, therefore, cannot be relied upon to answer the question that is at issue in this comment.

On an important side note, just because Israel cannot rely on Article 51 self-defense does not mean that it cannot take defensive measures at all. Emanuel Gross frustratingly writes, "[T]he central question-which the ICJ failed to recognize - was whether Israel had the right to defend itself against terrorist attacks." ${ }^{.151}$ What Gross fails to realize is that the Court unequivocally acknowledged that Israel "has the right, and indeed the duty, to respond [to terror attacks] in order to protect the life of its citizens."152 The Court merely found that such a right cannot be based on Article 51 of the U.N. Charter.

The right to take defensive measures in response to threats does not entail that these must qualify or should be justified as measures taken in self-defense under Article 51 of the Charter. To equate the two is simply to confuse the legal with the linguistic denotation of the term "defense." Just as "negligence," in law, does not mean "carelessness" but, rather, refers to an elaborate doctrinal structure, so "self-defense" refers to a complex doctrine that has a much more restricted scope than ordinary notions of "defense.", 153

\footnotetext{
Written Statement Submitted by Palestine, If 534 (Jan. 29, 2004), www.icj-cij.org/docket/files/131/ 1555.pdf.

147 OKIMOTO, supra note 89 , at 34.

148 Wall opinion, supra note 17, 95 (finding that the Fourth Geneva Convention, which applies to armed conflicts, applies to the Occupied Palestinian Territory).

149 Id.; see Scobbie, supra note 144, at 84.

150 Scobbie, supra note 144 , at 84.

151 Gross, supra note 138 , at 574.

152 Wall opinion, supra note 17, ๆ 141.

153 Scobbie, supra note 144 , at 84.
} 
Instead of Article 51, Israel can potentially rely on the doctrine of necessity, ${ }^{154}$ discussed in the next section, which is recognized by international customary law. ${ }^{155}$ In fact, the ICJ considered the construction of the wall under the doctrine of necessity, but found the doctrine could not be availed because the chosen route of the wall-running deep into the West Bank, thereby significantly impairing Palestinians' movement and resulting in the destruction of their property - was not the only means that Israel had to protect its interests. ${ }^{156}$ In any case, the right to take defensive measures is not legally equivalent to the right of self-defense under Article 51. ${ }^{157}$ Just because Israel does not have a right under Article 51 does not mean it has no right to protect its civilians under other legal doctrines.

Since the Court's opinion in 2004, Palestine has gained non-member observer State status at the U.N. General Assembly, which could have consequences for the applicability of Article 51 self-defense. The ICJ interpreted Article 51 to apply only to armed attacks from one State against another. ${ }^{158}$ In 2004, when the ICJ issued its Wall advisory opinion, Palestine was arguably not a "State." Its status at the U.N. General Assembly was only that of an "observer entity," which was first accorded to it in $1974 .^{159}$ In 2012, by a vote of 138 in favor and 9 against, the U.N. General Assembly voted to upgrade Palestine's status to that of non-member observer State. ${ }^{160}$ Since its status upgrade, Palestine has signed onto at least fifteen international treaties, which are available only to States. ${ }^{161}$ Even before the status upgrade, however, Palestine was recognized as a State by 130 governments and had joined the United Nations Educational, Scientific and Cultural Organization (UNESCO) as a member State. ${ }^{162}$ With its new status, Palestine was also able to accede to the Rome Statute, granting the International Criminal Court (ICC) jurisdiction to investigate crimes committed on Occupied Palestinian Territory. ${ }^{163}$ Before Palestine's status

154 Draft Articles on Responsibility of States, supra note 19, art. 25.

155 Wall opinion, supra note 17, 9 甲 142-43.

156 Id. 195.

157 Scobbie, supra note 144 , at 78.

158 Wall opinion, supra note 17, 1139.

159 Press Release, General Assembly, General Assembly Votes Overwhelmingly to Accord Palestine "Non-Member Observer State" Status in United Nations, U.N. Press Release GA/11317 (Nov. 29, 2012).

$160 I d$.

161 Ken Klippenstein, An Interview with Richard Falk on the Crisis in Gaza, COUNTER PUNCH (Aug. 13, 2014), www.counterpunch.org/2014/08/13/an-interview-with-richard-falk-on-the-crisis-ingaza; see Palestinians Sign Up to Join International Criminal Court, BBC NEwS (Dec. 31, 2014), www.bbc.com/news/world-middle-east-30645462 (writing that the PA signed on to twenty international treaties).

162 Klippenstein, supra note 161.

163 Press Release, Office of the Prosecutor, The Prosecutor of the International Criminal Court, 
upgrade, the ICC refused to open an investigation because Palestine was not a "State" within the meaning of the Rome Statute and, therefore, the ICC lacked jurisdiction. ${ }^{164}$ After Palestine's status upgrade, however, the ICC has opened a preliminary investigation into crimes committed on Palestinian territory. ${ }^{165}$ It also accepted Palestine as a member State party to the Rome Statute. ${ }^{166}$

With its status upgrade, Palestine is most likely a State for purposes of Article 51. If Article 51 self-defense applies, then it follows that as long as Israel's use of force was in line with the principles of necessity and proportionality in jus ad bellum as well as the rules of warfare in jus in bello or IHL, then force was probably legitimate and not for the illegitimate purpose of suppressing self-determination.

Despite Palestine's status upgrade, however, Article 51 likely still does not apply because the terror attacks at issue are not attributable to the State of Palestine. They are terror attacks launched by Hamas and some Bedouin groups in the Gaza Strip while the recognized authority of the territory is the Palestinian Authority led by President Mahmoud Abbas. The attacks, therefore, do not constitute an armed attack by one State against another. The ICC also stated, in an Article 53(1) Report issued after Palestine's status upgrade, that the Israel-Hamas conflict "do[es] not meet the basic definition of an international armed conflict as a conflict between two or more states." $" 167$

Furthermore, the language of the ICJ Wall opinion suggests that the Court found Article 51 irrelevant not because the Court did not find Palestine to be a State but rather because "Israel does not claim that the attacks against it are imputable to a foreign State."168 Regardless of Palestine's objective legal status, it seems Israel cannot avail itself of the self-defense argument while simultaneously denying Palestine's status as a State.

Fatou Bensouda, Opens a Preliminary Examination of the Situation in Palestine, I.C.C. Press Release ICC-OTP-20150116-PR1083 (Jan. 16, 2015).

164 Situation in Palestine, Office of the Prosecutor, ICC, at 2 (Apr. 3, 2012), www.icc-cpi.int/ NR/rdonlyres/9B651B80-EC43-4945-BF5A-FAFF5F334B92/284387/SituationinPalestine030412ENG. pdf.

165 ICC to Probe Possible War Crimes in Palestine, AL JAZEERA (Jan. 17, 2015, 11:30 AM), www.aljazeera.com/news/middleeast/2015/01/icc-probe-possible-war-crimes-palestine-2015116151720 780168.html.

166 Palestinian Authority Becomes Official Member of the International Criminal Court, HAARETZ (Apr. 1, 2015, 10:36 AM), www.haaretz.com/news/diplomacy-defense/1.650013?utm_ source=Facebook\&utm_campaign=Echobox\&utm_medium $=$ Social.

167 Situation on Registered Vessels of Comoros, Greece and Cambodia Article 53(1) Report, Office of the Prosecutor, ICC, \16 (Nov. 6, 2014), www.icc-cpi.int/iccdocs/otp/OTP-COM-Article 53\%281\%29-Report-06Nov2014Eng.pdf.

168 Wall opinion, supra note 17, 9139 (emphasis added). 
Since the ICJ's Wall opinion in 2004, Israel has disengaged from the Gaza Strip, which could affect the applicability of Security Council Resolutions 1368 and 1373. The Court rejected the self-defense argument under Resolutions 1368 and 1373 because the West Bank is under Israeli control; so, in the case of Operation Protective Edge, the question is whether Gaza is still under the control of Israel. Gaza's status as occupied territory since Israel's disengagement ${ }^{169}$ has been the subject of much debate. If Gaza is still considered to be under Israeli control, then Resolutions 1368 and 1373 are inapplicable, but if it is not, then Israel may have a valid self-defense justification for Operation Protective Edge. Once again, if the self-defense argument applies, then it follows that force was probably legitimate as long as it met the principles of necessity and proportionality in jus ad bellum as well as the rules of war in jus in bello or IHL.

Gaza's legal status has been under dispute since Israel withdrew its military from Gaza and dismantled settlements in the strip in $2005 .{ }^{170}$ Yuval Shany conducts a comparative analysis of the degree of effective control exercised by Israel and the Palestinian Authority (PA) and finds that the PA has greater powers of government than Israel. ${ }^{171}$ Therefore, he concludes that Israel can no longer be regarded as the occupying power in Gaza. ${ }^{172}$ Other scholars have argued under other theories and rationale for why Israel no longer occupies the Gaza strip. On the other hand, many in the international community, including the ICC, are of the opinion that Israel continues to occupy Gaza

based on the scope and degree of control that Israel has retained over the territory of Gaza following the 2005 disengagement - including, inter alia, Israel's exercise of control over border crossings, the territorial sea adjacent to the Gaza Strip, and the airspace of Gaza; its periodic military incursions within Gaza; its enforcement of no-go areas within Gaza near the border where Israeli settlements used to be; and its regulation of the local monetary market based on the Israeli

169 See generally Israel's Disengagement Plan: Renewing the Peace Process, ISRAEL MINISTRY OF FOREIGN AFFAIRS (Apr. 20, 2005), www.mfa.gov.il/mfa/foreignpolicy/peace/guide/pages/israels\% 20disengagement $\% 20$ plan-\%20renewing\%20the\%20 peace\%20process\%20apr\%202005.aspx.

170 See id.

171 Yuval Shany, Faraway, So Close: The Legal Status of Gaza After Israel's Disengagement, 8 Y.B. OF INT'L HUMANITARIAN L. 369 (2006); see also Avinoam Sharom, Why Is Israel's Presence in the Territories Still Called "Occupation"?, JERUSALEM CTR. FOR PUB. AfFAIRS (2009), http://jcpa.org/ text/Occupation-Sharon.pdf (concluding that occupation law does not apply to Gaza); Elizabeth Samson, Is Gaza Occupied? Redefining the Status of Gaza Under International Law, 25 AM. U. INT'L L. REV. 915 (2010).

172 Shany, supra note 171. 
currency and control of taxes and customs duties. ${ }^{173}$

It is beyond the scope of this Comment to fully analyze the debates on Gaza's legal status, especially when the "overwhelming consensus"174 and "prevalent view within the international community is that Israel remains an occupying power under international law." ${ }^{, 75}$ This Comment will proceed while assuming this prevalent view.

Because Israel continues to occupy Gaza, "[t]he situation is ... different from that contemplated by Security Council resolutions [1368 and 1373]." 176 The Resolutions refer to the inherent right of self-defense in the context of "international terrorism" but insofar as attacks emanate from territory which Israel controls, they do not constitute international terrorism. Thus, because Israel continues to control Gaza, attacks launched from Gaza do not constitute international terrorism. Therefore, just how Resolutions 1368 and 1373 did not apply to terror attacks emanating from the West Bank, so they do not apply to attacks that are launched from Gaza.

After extending the ICJ's analysis in the Wall opinion to Gaza, it seems that Article 51 self-defense is not applicable to the Gaza Strip either. Even though Palestine has now gained State status, attacks launched by Hamas do not constitute an armed attack from a State since the international community does not recognize Hamas as the legitimate authority of Palestine. Even if the international community did, still Israel does not recognize Palestine to be a State while the language of the Court's Wall opinion suggests that such recognition is a prerequisite to invoking Article 51 self-defense. Nor do Security Council Resolutions 1368 or 1373 seem to apply since they refer to international terrorism while terror attacks launched from Gaza emanate from within territory that Israel continues to control.

173 Situation on Registered Vessels of Comoros, Greece and Cambodia Article 53(1) Report, supra note 165, - 27; see also Duggard, supra note 12; Lisa Hajjar, Is Gaza Still Occupied and Why Does It Matter?, JADALIYYA (July 14, 2014), www.jadaliyya.com/pages/index/8807/is-gaza-stilloccupied-and-why-does-it-matter; Israel: Disengagement Will Not End Gaza Occupation, HuMAN RighTS WATCH (Oct. 29, 2004), www.hrw.org/news/2004/10/28/israel-disengagement-will-not-endgaza-occupation; The Gaza Strip: Israel's Obligations Under International Law, B'TSELEM (Jan. 1, 2015), www.btselem.org/gaza_strip/israels_obligations.

174 Valentina Azarov, Disingenuous "Disengagement": Israel's Occupation of the Gaza Strip and the Protective Function of the Law of Belligerent Occupation, OPINIO JURIS (Apr. 24, 2012), http:// opiniojuris.org/2012/04/24/disingenuous-disengagement-israels-occupation-of-the-gaza-strip-and-the-pr otective-function-of-the-law-of-belligerent-occupation ("[T] he vigorous academic debate concerning the current status of the Gaza Strip has arrived at an overwhelming consensus over the fact that the Gaza Strip remains occupied territory.”)

175 Situation on Registered Vessels of Comoros, Greece and Cambodia Article 53(1) Report, supra note 165, \16 (emphasis added).

176 Wall opinion, supra note 17, 139. 


\section{SECTION IV: THE DOCTRINE OF NECESSITY}

If not jus in bello, the law of occupation, or the law of self-defense, then perhaps the doctrine of necessity can help shed some light on the question of whether an occupying power used force to protect its civilians or to suppress self-determination. The doctrine of necessity is also known as "state of necessity," "essential interests doctrine," and the "plea of necessity."

The doctrine of necessity precludes the wrongfulness of a State's act that is not in conformity with international obligations. ${ }^{177}$ A State may invoke the doctrine of necessity if the only way that a State can protect an "essential interest" against a "grave an imminent peril" is by not fulfilling an international obligation of relatively less significance. ${ }^{178}$ The doctrine of necessity is codified in the Articles on Responsibility of States for Internationally Wrongful Acts, which was adopted by the International Law Commission in 2001. It is also recognized as customary international law ${ }^{179}$ as confirmed by the ICJ for the first time in its Gabcikovo-Nagymaros Project decision. ${ }^{180}$ The doctrine can only be invoked under strict conditions defined in Article 25 of the Articles. ${ }^{181}$ Furthermore, it cannot be invoked if "the international obligation in question excludes the possibility of invoking necessity" or "the State has contributed to the situation of necessity." 182

While the plea of necessity was historically only related to the concept of self-preservation and other essential State interests, today it also encompasses human security interests. ${ }^{183}$ Necessity has been invoked to safeguard essential interests such as protecting the environment ${ }^{184}$ and ensuring the safety of civilians. ${ }^{185}$

An early successful case of necessity was the Caroline incident, which is usually wrongly referred to as a case of self-defense. ${ }^{186}$ In that case in 1837, British forces destroyed a United States vessel carrying recruits and arms to Canadian insurgents who wanted to rebel against the British Crown.

177 Draft Articles on Responsibility of States, supra note 19, art. 25.

$178 \quad$ Id.

179 Contra Sarah Heathcote, Is State of Necessity a Principle of Customary International Law? 1 REVUe BELGE DE DROIT INT'L 53 (2007) (writing that State practice does not support the assertion, prevalent in judicial decisions, that the doctrine of necessity is customary international law).

180 Gabcikovo-Nagymaros Project (Hung./Slovk.), 1977 I.C.J. 7 (Sept. 25).

181 Draft Articles on Responsibility of States, supra note 19, at art. 25.

182 Id. at art. 25(2)(a)-(b).

183 Ian Johnston, The Plea of "Necessity" in International Legal Discourse: Humanitarian Intervention and Counter-Terrorism, 43 COLUM. J. TRANSNAT’L L. 337, 340 (2004-05).

184 Gabcikovo-Nagymaros Project, supra note 180.

185 Wall opinion, supra note 17, 1 甲 140-43.

186 Draft Articles on Responsibility of States, supra note 19, art. 25 cmt. (5). 
The British justified the destruction of the vessel by referring to the "necessity of self-defence and self-preservation." ${ }^{187}$ United States Secretary of State Webster stated in his message to Congress, "This government can never concede to any foreign Government the power, except in a case of the most urgent and extreme necessity, of invading its territory." "188 The incident was finally settled in 1842 when the British and American governments agreed that "a strong overpowering necessity may arise when this great principle may and must be suspended."189

In order to safeguard against abuse, the plea is only accepted on an exceptional basis. ${ }^{190}$ The ICJ in the Wall opinion, for example, considered whether Israel could rely on the doctrine of necessity for its construction of the wall in the West Bank. ${ }^{191}$ The essential interest that Israel was safeguarding was the safety of its civilians. However, the ICJ found that the facts of the case did not meet the strict conditions under which necessity can be invoked. ${ }^{192}$ One of those conditions is that the wrongful act be "the only way for the State to safeguard an essential interest."193 The particular route of the wall, the ICJ found, was not the only means at Israel's disposal to safeguard its interest. Israel could have, for example, built the wall on its side of the Green Line instead of miles into the West Bank.

It is important to note that the ICJ did not address the fact that Israel could never successfully invoke the plea of necessity in the Wall case since its construction violated the preemptory norm of self-determination. ${ }^{194}$ Article 26 of the Articles excludes the possibility of invoking the plea of necessity if the wrongful act "is not in conformity with an obligation arising under a preemptory norm of general international law." 195 The commentaries to the Articles explicitly list respecting the right to selfdetermination as an example of a preemptory norm from which no derogation is possible even under the doctrine of necessity. ${ }^{196}$ The ICJ found that the wall "severely impedes the exercise by the Palestinian people of its right to self-determination and is therefore a breach of Israel's

187 LORD MCNAIR, 2 INTERNATIONAL LAW OPINIONS 228 (1956).

188 BRITISH AND FOREIGN STATE PAPERS, 1841-1842 vol. 30 at 194 (1857), http://hdl.handle.net/ $2027 /$ mdp.35112103940203.

189 Id. at 196.

190 Draft Articles on Responsibility of States, supra note 19, art. 25 cmt.(2).

191 Wall opinion, supra note 17, 9 ๆ 140-43.

192 Id. at 142.

193 Draft Articles on Responsibility of States, supra note 19, art. 25.

194 Sarah Heathcote, Circumstances Precluding Wrongfulness: Necessity, in THE LAW OF INT'L RESPONSIBILITY 491, 500 (James Crawford et al. eds., 2010).

195 Draft Articles on Responsibility of States, supra note 19, art. 26.

196 Id. at art. $26 \mathrm{cmt}$. (5). 
obligation to respect that right." 197 Given that the Court had already concluded that the wall violated the right to self-determination-a preemptory norm - it was unnecessary for it to even conduct the plea of necessity analysis. The plea is unavailable if the wrongful act violates a preemptory norm.

Nevertheless, even though the plea of necessity was unsuccessful in the particular instance of the wall in the West Bank, the Wall opinion shows that Israel can in principle rely on necessity to use force against terror attacks emanating from the Occupied Palestinian Territory. That is as long as it does not violate the obligation to respect the Palestinians' right to self-determination in the process. In effect this means that the doctrine of necessity does not help answer the question whether force was used to protect civilians or to suppress self-determination. This is because necessity precluding the wrongfulness of an act presumes a wrong act, which brings us back to the question whether force was in fact wrong (i.e., for the purpose of suppressing self-determination).

In the Wall opinion, for example, the construction of the wall was wrong because it violated several provisions of the Fourth Geneva Convention and the Hague Regulations, including the destruction of private property of the occupied inhabitants, as well as several provisions of the International Covenant on the Civil and Political Rights. ${ }^{198}$ The doctrine of necessity was considered by the ICJ only after the wrongfulness of the wall was established. ${ }^{199}$ But how is one to know whether force in Operation Protective Edge was wrongfully used to suppress the Gazans' struggle for self-determination? This is the very question that this Comment seeks to answer. Even determining whether the plea of necessity is excluded under Article 26 requires a preliminary determination of whether force violated the preemptory norm of the right to self-determination. Applying the doctrine of necessity itself necessitates answering the question at issue in this Comment. It, therefore, does not help to determine whether force by an occupying power was used to protect civilians or to suppress selfdetermination.

\section{SECTION V: INTRODUCTION TO THE TWO-FACTOR TEST}

Neither jus in bello, occupation law, the law of self-defense, nor the doctrine of necessity offer appropriate guidance to determine whether force used by an occupying power was to protect its civilians or to suppress a people's right to self-determination. Jus in bello is inapplicable to the

\footnotetext{
197 Wall opinion, supra note 17, 9122.

198 Id. ๆๆ 132-34.

199 Id. $\uparrow 140$.
} 
question at hand since it merely governs how armed hostilities are conducted once they have begun, and is unconcerned with the motives behind the use of force. Furthermore, occupation law in general is inapt to deal with the question since it developed outside the context of colonial occupation and, therefore, does not account for self-determination. The law of self-defense, Article 51 of the U.N. Charter specifically, is inapplicable against attacks launched by Hamas since it is not a State actor and Article 51 is traditionally interpreted as applying only to force used by one State against another. Nor is the new conceptualization of self-defense under U.N. Security Council Resolutions 1368 and 1373, which extends to international terrorism from non-State actors, relevant because the Occupied Palestinian Territory (including Gaza) is within the control of Israel. Attacks emanating from within the Occupied Palestinian Territory, therefore, do not constitute "international terrorism" under the Resolutions. ${ }^{200}$ As for the doctrine of necessity, it presumes a wrong act, which brings us back to the question of whether force was indeed wrong (i.e., was it used to suppress self-determination?). None of these legal regimes or doctrines directly or even indirectly answers the question at issue in this Comment. Neither forms an appropriate legal basis for determining the issue at hand.

It follows, therefore, that tackling the question would require a factual determination on a case-by-case basis. The ICJ in the Wall case, for example, found that the wall in the West Bank violated the Palestinians' right to self-determination because it created a "fait acompli," which would eventually become permanent and be "tantamount to de facto annexation." ${ }^{201}$ It determined so after carefully considering all facts and arguments both defending the wall (including the argument that the wall is a temporary structure to be dismantled upon a final resolution to the conflict) and opposing it. ${ }^{202}$ The Court did not refer to any law or legal test as the basis for its determination, which we now know is because such a legal basis does not exist. A similar factual determination is required to determine whether force used in Operation Protective Edge was for the legitimate purpose of protecting civilians or for suppressing the struggle for self-determination.

This Comment proposes a two-factor test to help with the factual determination. The test involves the following two factors: (1) was force necessary to combat the threat to Israel's inhabitants; and (2) did force go beyond that which was necessary to combat the threat? "Necessary" under 
the first factor means that no viable non-forceful alternatives were available. If force was not necessary to protect inhabitants because other means of protection were available and feasible, then this is an indication that force was for the illegitimate purpose of suppressing selfdetermination. The condition that alternative means be feasible anticipates situations when other means may be available but not feasible for reasons such as temporal constraints. A threat may be imminent while non-forceful means may take time to implement.

When it comes to the second factor, if an occupying power is indeed protecting its inhabitants, it would use only so much force as is necessary to combat the threat and no more. The concept is similar to Daniel Webster's statement during the Caroline affair, "the act justified by the necessity ... must be limited by that necessity and kept clearly within it." ${ }^{203}$ If force goes beyond that which was necessary to protect inhabitants, then the excess is likely for the illegitimate purpose of suppressing self-determination.

The two-factor test should not be confused with either the doctrine of necessity precluding the wrongfulness of an act or jus ad bellum necessity. While the two-factor test is similar to some of the conditions of the doctrine of necessity, the legal status and the purpose of the two are completely different. While the doctrine of necessity is customary international law that precludes the wrongfulness of an act, the two-factor test is simply a nonexhaustive list of factors that a fact-finder may employ to determine the purpose of the use of force by an occupying power. Sequentially, the twofactor test comes earlier in the analysis than the doctrine of necessity.

Nor should the two-factor test be confused with jus ad bellum necessity. While the two seem extremely similar in their content, they are wholly different in their legal status and purpose. The factors are just thatfactors. They simply help make a factual determination regarding the purpose behind the use of force by an occupying power. Unlike jus ad bellum necessity, the factors do not form a legal basis for the use of force. This Comment has already established that Israel cannot rely on any legal basis, except the doctrine of necessity, to use force against attacks launched by Hamas in Gaza. The factors simply help determine whether the force used by Israel was indeed for the purpose of protecting its inhabitants or whether its aim was to suppress the Gazans' right to self-determination.

The second factor should not be confused with jus in bello proportionality as the two seem very similar. Jus in bello proportionality is concerned with whether the harm to civilian life and property was

203 Nicholas Tsagourias, Necessity and the Use of Force: A Special Regime, 41 NETHERLANDS Y.B. OF INT'L L. 11, 15 (2011). 
proportional to the direct and concrete military advantage sought. ${ }^{204} \mathrm{Jus}$ in bello proportionality, in other words, tries to weigh the cost to civilian life and property against the military gain achieved. The second of the two factors proposed in this Comment, however, does not consider the harm to civilian life or property at all. Nor does it involve a weighing of the harm against the military advantage gained. Rather, the second factor is only concerned with whether the force used, regardless of whether or not it was proportional to the military advantage sought, went beyond that which was necessary to combat the threat at hand. The harm from the use of force could be wholly disproportional to the military advantage sought and yet be within the limits of that which is necessary to combat the threat at hand.

The two factors are simply considerations that a fact-finder should take into account when making a factual determination on the purpose behind the use of force by an occupying power. They help ground the analysis and provide some level of uniformity in analyses from case to case. The factors neither are conclusive in and of themselves nor do they constitute an exhaustive list of factors to consider when making a factual determination. Rather, they should be used alongside other relevant considerations, if any, and should be viewed within the larger context of the occupation at issue.

\section{SECTION VI: APPLYING THE TWO-FACTOR TEST to OPERATION PROTECTIVE EDGE-GAZA'S TUNNELS}

One of the officially stated purposes of Operation Protective Edge was to destroy the "terror tunnels." 205 These tunnels, built by Hamas, reach up to thirty meters below the ground. ${ }^{206}$ They run across the border from Gaza into Israeli territory. According to Israeli Prime Minister Netanyahu, the Israeli army, and other Israeli officials, the "sole purpose" of the tunnels was to kill Israeli civilians, ${ }^{207}$ although it is more likely that the target of the tunnels were Israeli soldiers. ${ }^{208}$ It was through a tunnel that Hamas had

204 Adil Ahmad Haque, A Theory of Jus in Bello Proportionality, in WeIGHING LiVES: COMBATANTS \& CIVILIANS IN WAR (Jens Ohlin et al. eds., forthcoming 2016), www.academia.edu/ 11341774/A_Theory_of_Jus_in_Bello_Proportionality.

205 The IDF's Mission in Gaza: Destroy Hamas Terror Tunnels, IDF BLOG (July 17, 2014), www.idfblog.com/blog/2014/07/17/idf-begins-ground-operation-gaza.

206 Inside the Tunnels Hamas Built: Israel's Struggle Against New Tactic in Gaza War, THE GUARDIAN (Aug. 2, 2014, 10:16 AM), www.theguardian.com/world/2014/aug/02/tunnels-hamas-israelstruggle-gaza-war.

207 Aaron Klein \& Mitch Ginsburg, Could Israeli Soldiers, Not Civilians, Be the Target of the Attack Tunnels?, TIMES OF ISRAEL (July 29, 2014, 1:03 PM), www.timesofisrael.com/soldiers-notcivilians-are-tunnel-infiltration-goals-says-senior-intelligence-source; Emanual Yalin, Were Gaza Tunnels Built to Harm Israeli Civilians?, 972 MAG (Aug. 11, 2014), http://972mag.com/were-gazatunnels-built-to-harm-israeli-civilians/95279.

208 Klein \& Ginsburg, supra note 207; Yalin, supra note 207 (citing leader of Hamas' Qassam Brigade's interest in targeting Israeli soldiers over civilians). 
kidnapped Israeli soldier, Gilad Shalit, in 2006, who was later released in 2011 in a prisoner swap deal. ${ }^{209}$ All tunnels leading into Israel opened within a few hundred meters of the Israel-Gaza border, and none opened into civilian communities. ${ }^{210}$

While Israel had known about the existence of the tunnels "for some time," it was not aware of just how vast and effective the tunnel system was. ${ }^{211}$ This discovery was made after Israel had already launched Operation Protective Edge. Upon discovery of the tunnels, according to some Israeli officials, the objective of the operation shifted from stopping Hamas rocket fire to destroying the tunnels. ${ }^{212}$ According to the Israeli military, there were forty such tunnels of which fourteen connected to Israel. $^{213}$

Applying the first factor of the two-factor test, it is clear that the use of force was not necessary to combat the threat posed by the tunnels because of the availability of viable non-forceful alternatives. While there were fourteen tunnels that connected to Israel, there were around 1,400 that lead to Egypt. ${ }^{214}$ The tunnels to Egypt were used to smuggle in goods after Israel imposed a siege on Gaza, which crippled its economy and led to the development of an active underground trade. ${ }^{215}$ The tunnel trade with Egypt was essential for Gaza's economy following the imposition of the siege in 2007. In one incident, militants also used the tunnels to cross into Egypt where they gunned down sixteen Egyptian border guards. ${ }^{216}$ General Sisi of Egypt neutralized the threat of the tunnels by simply sealing them off at the Egyptian side of the border. ${ }^{217}$ In some cases, Egypt flooded the tunnels. ${ }^{218}$

209 Timeline 1,940 Days from Gilad Shalit's Abduction to His Release, supra note 6.

210 Id.; Klein \& Ginsburg, supra note 207. Reports on tunnels leading to Israeli kindergartens and other civilian areas were later discovered to be false. James North \& Phil Weiss, Tunnels-toKindergartens Propaganda Netanyahu Peddled to NYT and CNN Is Exploded by Israeli News Site, MONDOWEISS (Aug. 13, 2014), http://mondoweiss.net/2014/08/kindergartens-propaganda-netanyahu.

211 Inside the Tunnels Hamas Built: Israel's Struggle Against New Tactic in Gaza War, supra note 206.

212 Asa Fitch et al., Early Failure to Detect Gaza Tunnel Network Triggers Recriminations in Israel, WALL ST. J. (Aug. 10, 2014), www.wsj.com/articles/gaza-tunnel-network-fuels-recriminationsin-israel-1407714903.

213 Alejandra Azuero-Quijano, Gaza's Tunnel Paradox, Al JAZEERA AMERICA (Aug. 14, 2014, 6:00 AM), http://america.aljazeera.com/opinions/2014/8/gaza-tunnel-siegeisraelidfblockade.html.

214 Egyptian Military Says It Destroyed 1,370 Gaza Smuggling Tunnels, THE NATIONAL (Mar. 12, 2014, 8:49 PM), www.thenational.ae/world/palestinian-territories/egyptian-military-says-itdestroyed-1-370-gaza-smuggling-tunnels.

215 Is the Closure of the Tunnels from Egypt Further Suffocating the Gaza Economy?, UNISPAL (Feb., 2014), https://unispal.un.org/pdfs/WFP_SpFocus-GazaTunnels.pdf.

216 Egypt Moves to Seal off Gaza Smuggling Tunnels, JERUSALEM Post (Aug. 7, 2012, 5:15 PM), www.jpost.com/Middle-East/Egypt-moves-to-seal-off-Gaza-smuggling-tunnels.

217 Id.; Gaza Ceasefire: After 1,800+ Dead, What Led Israel to Stop the Assaul-And What Comes Next? DEMOCRACY Now! (Aug. 5, 2014), www.democracynow.org/2014/8/5/ceasefire_after_ 
Egypt did not have to go into Gaza and use devastating force in order to deal with the tunnel threat.

In fact, non-forceful measures were available to Israel for years before Operation Protective Edge. The Israeli Defense Ministry was considering digging a moat around Gaza to stop the tunnels as far back as the year $2000 .^{219}$ It had spent several years and a significant amount of money on the idea. ${ }^{220}$ It was not as if using force was the better or more effective option. In fact, because the tunnels were deep below the ground, they were not vulnerable to bombs or artillery shells. ${ }^{221}$

Applying the second factor of the two-factor test, the force used by Israel went beyond that which was necessary to combat the threat posed by the tunnels, indicating a motive other than the neutralization of a threat to its inhabitants. For example, Israel struck United Nations Relief Works Agency (UNRWA) schools sheltering displaced Palestinians multiple times despite the fact that the UNRWA had informed the Israeli military of the schools' coordinates multiple times. ${ }^{222}$ Striking the schools, which resulted in the deaths of forty-seven civilians, ${ }^{223}$ was completely unnecessary to combat the threat posed by the tunnels. It was also unnecessary to stop rocket attacks, the second stated purpose of Operation Protective Edge, since the schools were not housing Hamas members or rockets. While the UNRWA found Hamas rockets stored in some of the agency's schools, these were not the schools that Israel targeted. ${ }^{224}$ Following Operation Protective Edge, Amnesty International published a report, which revealed "a pattern of frequent Israeli attacks using large aerial bombs to level civilian homes, sometimes killing entire families." ${ }^{225}$ Amnesty International found that some of the attacks served no military purpose. ${ }^{226}$ The lack of military purpose for the strikes on homes goes beyond that which was

gaza_assault_leaves_1800.

218 Abeer Ayyoub, Egypt Floods Gaza's Smuggling Tunnels, AL MONITOR (Feb. 21, 2013), www.al-monitor.com/pulse/en/contents/articles/originals/2013/02/egypt-floods-gaza-tunnels.html\#.

219 Early Failure to Detect Gaza Tunnel Network Triggers Recriminations in Israel, supra note 212.

$220 \quad I d$.

221 Gaza Ceasefire: After 1,800+ Dead, What Led Israel to Stop the Assault-And What Comes Next?, supra note 217.

222 Raya Jalabi et al., Gaza Crisis: A Closer Look at Israeli Strikes on UNRWA Schools, THE GuARDIAN (Aug. 8, 2014, 2:31 PM), www.theguardian.com/world/2014/aug/08/-sp-gaza-israeli-strikesunrwa-schools.

$223 I$ Id.

224 See Israel/Gaza: Attack on U.N. School in Gaza a Potential War Crime That Must Be Investigated, AMNESTY INTERNATIONAL (July 30, 2014), www.amnesty.org/en/news/israelgaza-attackun-school-gaza-potential-war-crime-must-be-investigated-2014-07-30.

$225 I d$.

$226 I d$. 
necessary to combat the threat of the tunnels (or even the threat posed by Hamas rockets). This indicates a motive other than the protection of Israeli lives.

Furthermore, at least 120 Palestinians were killed during the Shujaiyah assault. ${ }^{227}$ Israeli soldiers allegedly drew an imaginary, arbitrary red line and shot anyone who crossed it, whether civilian or combatant. ${ }^{228}$ Four of Mohammed Fathi Al Areer's brothers, including his mentally disabled sibling, were shot in cold blood. ${ }^{229}$ Israeli soldiers also shot dead four unarmed members of the Shamaly family after breaking into their home. ${ }^{230}$ A fifth member of the Shamaly family was shot while he was searching among the rubble for his family members during a temporary ceasefire. ${ }^{231}$ The indiscriminate force used in Shujaiyah went well beyond that which was necessary to combat the threat of either the tunnels or Hamas rockets. The intentional targeting of civilians without military purpose achieves nothing towards the end of destroying the tunnels or killing Hamas members in order to protect Israeli inhabitants. The excessive use of force without military purpose indicates a motive other than the protection of Israeli lives.

Therefore, the use of force was not necessary to combat the threat posed by the tunnels as Israel could have simply sealed them off or flooded them like Egypt did. Additionally, in several instances, the force Israel used went far beyond that which was necessary to destroy the tunnels (or even to stop the rocket attacks), indicating that the motive behind the use of force was something other than the protection of Israeli lives.

Other considerations that support this finding are certain statements made by Israeli officials and certain official Israeli policies. Israeli officials have themselves stated their intentions to suppress the Gazans' struggle for self-determination or destroy their national liberation movement. It is openly admitted by Israeli officials, including those in the Defense Ministry, that the aim of Israel's policy towards Gaza is to make life so miserable for Gazans that it forces them to turn against the government of Hamas. ${ }^{232}$ Following Operation Cast Lead in 2008-2009, Israeli Prime

227 Peter Beaumont, Gaza Crisis: Palestinian Death Toll Climbs Past 500 as Hospital Is Hit, THE GUARDIAN (July 21, 2014), www.theguardian.com/world/2014/jul/21/gaza-crisis-obama-ceasefirefighting-goes-on.

228 The Untold Story of the Shejaiya Massacre in Gaza: A Former Israel Soldier Speaks Out, DEMOCRACY NOw! (Sept. 12, 2014), www.democracynow.org/2014/9/12/the_untold_story_of_the_ shejaiya.

229 Id.

$230 \quad I d$.

231 Id.

232 Nicholas Kristof, Winds of War in Gaza, N.Y. TIMES (Mar. 7, 2015), www.nytimes.com/ 2015/03/08/opinion/sunday/nicholas-kristof-winds-of-war-in-gaza.html?_r=1; see Yossi Wolfson, 
Minister Netanyahu stated that the operation should have lasted longer so the IDF could have toppled Hamas. ${ }^{233}$ Toppling or weakening the resistance capacity of an elected government (and also a liberation group) is probably the clearest violation of the obligation to respect the right to selfdetermination. Most recently, Israeli Prime Minister Netanyahu said in an interview in March of 2015 that as long as he is in power, he will not allow the creation of a Palestinian State. ${ }^{234}$ Meanwhile, in 2001, a camera caught Netanyahu describing how he manipulated the peace process in a way that would have left the Oslo Accords null and void. ${ }^{235}$

When considering the above in light of the fact that the occupation has been running for forty-eight years, it becomes even more likely that the aim of Operation Protective Edge was not simply to protect Israelis, but rather to stop Palestinian resistance all together. The head of the IDF's Planning Division stated that the aim of Operation Protective Edge was to return to the status quo, which he described as a "calm in the south." ${ }^{236}$ But to return to a "calm" effectively means to return to a situation of no resistance while the siege and control of Gaza's borders, waters, and airspace continues. Insofar as the aim was for the Palestinians to give up any and all resistance and acquiesce to their condition, it is a violation of the obligation to respect their right to self-determination. Echoing John Duggard's conclusion, the purpose of Israel's use of force, in light of the two-factor test and surrounding circumstances, seems to be defending its occupation rather than defending its people.

\section{SECTION VII: CONCLUSION}

As the law currently stands, no legal basis exists to ground an answer to the question of whether force used by an occupying power was for the purpose of protecting its inhabitants or for suppressing a people's struggle for self-determination. Although the ICJ concluded in the Wall opinion that IHL applies to the Occupied Palestinian Territory, the jus in bello legal

Economic Warfare in Gaza, THE ELECTRONIC INTIFADA (Jan. 21, 2008), http://electronicintifada.net/ content/economic-warfare-gaza/7308; Gaza on Brink of Implosion as Aid Cut-off Starts to Bite, THE GUARDIAN (Apr. 15, 2006), www.theguardian.com/world/2006/apr/16/israel; Israel Used "Calorie Count" to Limit Gaza Food During Blockade, Critics Claim, The GuARDiAn (Oct. 17, 2012), www.theguardian.com/world/2012/oct/17/israeli-military-calorie-limit-gaza.

233 Herb Keinon, Netanyhu: Toppling Hamas Remains an Option, JERUSALEM Post (Aug. 30, 2014), www.jpost.com/Israel-News/Politics-And-Diplomacy/Netanyahu-Toppling-Hamas-remains-anoption-372828.

234 Elliot McLaughlin, Israel's PM Netanyahu: No Palestinian State on My Watch, CNN (Mar. 16, 2015), www.cnn.com/2015/03/16/middleeast/israel-netanyahu-palestinian-state.

235 Netanyahu in 2001: America Is a Thing You Can Move Very Easily, HufFINGTON Post (May 25, 2011),www.huffingtonpost.com/2010/07/16/netanyahu-in-2001-america_n_649427.html?.

236 Yoav Zitun, Ya'alon Reiterates: Israel Chose Not to Topple Hamas During Gaza Op, YNET NEWS (Sept. 30, 2014), www.ynetnews.com/articles/0,7340,L-4576235,00.html. 
regime is irrelevant to the question posed in this Comment. Jus in bello only deals with how warfare is conducted once an armed struggle begins and is not concerned with the motives behind the use of force. Nor is the law of occupation, in general, relevant to this question because the law of occupation was developed outside the context of colonial occupations and, thus, does not take into account issues of self-determination. The law of self-defense is an inappropriate legal basis to ground an analysis since Article 51 of the U.N. Charter self-defense traditionally only applies to an armed attack by one State against another. Israel does not recognize Palestine as a State, and even if it did, the attacks were launched by Hamas, which is a non-State actor. Nor does the new conceptualization of selfdefense under U.N. Security Council Resolutions 1368 and 1373, which encompasses armed attacks by non-State actors, apply since the relevant attacks emanate from territory within the control of Israel. Therefore, they do not constitute the type of "international terrorism" to which the Resolutions refer. Lastly, while the doctrine of necessity can apply to Israel's use of force, it does not form an appropriate legal basis to ground analysis of the issue at play in this Comment either. The doctrine of necessity presumes a wrong act, which brings us back to the question of whether force used by an occupying power was indeed wrong (i.e., whether it was used to suppress the right to self-determination).

Absent an appropriate legal basis, answering the question requires a case-by-case factual determination. The purpose of the two-factor test, proposed in this Comment, is to assist with that factual determination and provide some level of uniformity in analyses from case to case. Application of the two-factor test to the issue of tunnels leading from Gaza to Israel shows that Israel likely used force during Operation Protective Edge to suppress Palestinian resistance rather than to protect its inhabitants. Using bombs and artillery shells to destroy the tunnels, resulting in a large number of casualties, was not the only viable means with which Israel could combat the threat of the tunnels. Israel could have simply sealed the tunnels at its end or flooded them like Egypt did. Additionally, the force used was excessive and went beyond that which was necessary to combat the threat of tunnels (or even the threat posed by Hamas rockets). Both these factors are indicators of an intent to suppress Palestinian resistance rather than protect Israeli inhabitants. When considered within the larger context, including how long the occupation has lasted, statements made by Israeli officials, the crippling siege of Gaza, and certain official Israeli policies, it becomes even more likely that force was part of a larger policy to suppress Palestinian self-determination. Operation Protective Edge, it appears, was about defending the occupation rather than defending Israelis. 